\title{
POST-FIRE SUCCESSION ON ABANDONED FIELDS IN CONIFEROUS FOREST HABITAT (NORD-EAST POLAND)
}

\author{
ANNA JUSTYNA KWIATKOWSKA-FALIŃSKA \\ Białowieża Geobotanical Station of Warsaw University \\ Sportowa 19, 17-230 Białowieża, Poland \\ e-mail: sekretariat.bsg@uw.edu.pl
}

(Received: March 27, 2007. Accepted: August 13, 2007)

\begin{abstract}

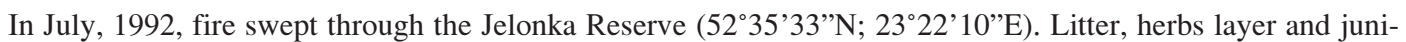
per shrubs were razed and the tree trunks of Pinus sylvestris and Populus tremula damaged, which resulted in their death the following year. Five research plots of $25 \mathrm{~m}^{2}$ each were established in the post-fire area. The species present there and their degrees of coverage were listed on the Londo scale between 1993 and 2002. The calculation of average degrees of coverage for individual populations allowed for the establishing of a chronological pattern of post-fire succession. The following findings have been made: 1) the primary function in colonization belongs to species of guerilla strategy of growth whose dormant buds survived fire underground (Holcus mollis, Calluna vulgaris and Populus tremula) or phalanx strategy of growth (Corynephorus canescens); 2) the dominants of the initial succession stage are perennial grasses, not therophytes; 3 ) the spatial pattern of succession is influenced by the occurrence of $H$. mollis or $C$. canescens in a particular location; 4) the initial stage terminates with the occurrence and further growth of $C$. vulgaris clumps; the post-fire succession in the Jelonka Reserve attained a brushwood stage faster in comparison to secondary succession, formerly triggered by the cessation of cultivation on arable land.
\end{abstract}

KEY WORDS: secondary succession; spatial patterns; temporal patterns; species turnover; fire; abandoned fields.

\section{INTRODUCTION}

\section{General characteristics of fires}

Fire in a seasonaly hot and dry climate fulfils an essential function in species selection and the creation of specific flora communities (e.g. macchia; Kornaś 1958).

Prolonged droughts in Poland occur seldom in comparison with e.g. the Mediterranean climate zone. The threat of fire to forests in Poland mainly results from additional factors. The majority of Polish forests cover the poorest sandy habitats, which are unsuitable for agricultural use. The good drainage of sandy soils is responsible for their periodic dryness. Productive forests are predominated by particularly fire-susceptible coniferous species (mainly Pinus sylvestris). Fire propagation in such forest-stands is the most intense owing to the resin content in branches and tree trunks, and the forest floor covered with fire-susceptible needles and cones. Additionally, the majority of coniferous forest stands consist of young specimens, which are more susceptible to fire.

Fire intensity, apart from climatological conditions, also depends on the species composition of undergrowth, the type and humidity of litter and the landscape form determining the speed of fire propagation. The fire level in ground fires ranges from several to $200 \mathrm{~cm}$, and their propagation attains speeds most often from 1 to $5 \mathrm{~m} /$ minute. Ground fires consume litter, herbs layer and tree species of the shrub-layer. The propagation speed of fires affecting canopies is significantly higher, and ranges from $40 \mathrm{~m}$ to 400 $\mathrm{m}$ per minute. The temperature created during ground fires reaches up to $400^{\circ} \mathrm{C}$, and during the total burning of a forest stand can even be twice higher (Wiler 1996).

The objective of this work is to answer the question of whether the process of post-fire succession develops according to the same model of secondary succession with respect to stage sequence and the timing of stages on abandoned fields. The data analyzed in this work refer to a process evolving over 12 years. According to Faliński, secondary succession, undisturbed by fire, reaches the 2nd-4th stage within this period.

The analysis of post-fire succession has been based on unpublished materials of Professor J.B. Faliński. They were prepared after his death (11.11.2004). Therefore the results of the used material and the idea for this work could not, unfortunately, be shared with him.

\section{Study area and subject}

The Jelonka Reserve (52³5'33'N; 2322'10”E), established in 1998, is located in a peripheral part of Białowieża Forest, only $10 \mathrm{~km}$ from its south-western border. The re- 
serve includes 227 ha of fields abandoned at different periods, at the present time covered with spontaneous vegetation. The reserve was established to protect both the ecological secondary succession process and the evolved plant communities. The majority of former fallow lands (95\%) is found on mineral soils. The soils originate from sands with a low clay content, which often form the deepest layers of the discussed soil profile (Faliński 1993).

Research carried out on the secondary succession concerning abandoned fields was initiated by Professor J.B. Faliński in 1970. Permanent research areas were established the same year on the fields which were abandoned in different periods. Research on the biodiversity of the reserve, carried out in co-operation with a team of specialists in cryptogamous plants, has shown the local plant cover to be relatively rich, despite the poor habitat. Over 150 species of vascular plants, 40 species of bryophytes and over 60 species of lichens have been found there (Faliński and Holeksa 1993; Czyżewska 1993; Cieśliński 1993).

According to Faliński (1998) there are 8 stages of succession to be distinguished in the reserve. The model of secondary succession has been established by Faliński (1986a, b), based on phytosociological comparative studies and dendrochronological dating. According to this author, the subsequent stages of succession are as follows (Faliński 1998):

Stage 0 (Teesdaleo-Arnoseridetum): a weed community with a low number of species, co-existing with remaining cereals (rye, oat, potato), present in the first year after cessation of cultivation.

Stage 1 (Koelerio-Astragaletum arenariae): fresh fallow. The stage lasts for 1-2 years; pioneering stage of sand grassland, fully established in the subsequent stages (4 to 6 years). Field weeds still remain at this stage.

Stages 2, 3 and 4 (Spergulo-Corynephoretum cladinietosum): grass-herb sand grassland accompanied by lichen communities. The stage lasts from 2 nd do 15 th year. Stage 2 is initiated by the appearance of Thymus serpyllum and Astragalus arenarius. In stage 3 numerous seedlings of $J u$ niperus communis occur. The first 9-10-year-old juniper specimens start flowering at stage 4 . At the end of this stage the ratio between the area covered by sand grassland and lichen communities is established at approximately 4 (or 5) to 1 .

Stages 5 and 6 - complex of communities: Spergulo-Corynephoretum + Koelerio-Astragaletum + CornicularioCladonietum. Grass-herb sand grassland and lichen communities are established as a complex with juniper stands. The stage lasts from 12th to 25th year. At this stage the juniper specimens grow intensely, expanding vertically and horizontally. The female juniper specimens attain their generative phase. The population of juniper increases in number and its juvenile specimens mainly originate from local sowing. At the end of the 6th stage single pine and aspen specimens grow out above the grassland, not yet creating clumps.

Stage 7 - juvenile brushwood community (Juniperus communis - Populus tremula - Pinus sylvestris). The initial stage of the formation of juniper-aspen brushwood. The stage lasts from 25th to 45 th year. The area covered by grassland decreases and the density of juniper specimens increases. The lichen communities specific for open areas withdraw, and willow specimens occur. The species of bry- ophytes and lichens (e.g. Pleurozium schreberi and Cladonia sylvatica) characteristic for coniferous forests occur under the umbrella of trees and shrubs.

Stage 8 - brushwood community (Juniperus communis Populus tremula - Pinus sylvestris). Juniper-aspen brushwood of high density. The stage lasts for 40th to 70th year. Specimens of Populus tremula, Pinus sylvestris, Betula pendula and Picea abies begin to enter the tree-layer. Numerous species of spermatophytes and bryophytes typical for coniferous forests are found in the ground-layer and moss-layer.

In the summer (2 July, 1992) a part of Jelonka Reserve was destroyed by a forest fire of several hours' duration (from $1.00 \mathrm{pm}$ to $7.00 \mathrm{pm}$ ). The fire totally destroyed the litter, ground-layer and shrub-layer, and it damaged the trunks and canopies of young pine trees. The process of succession had been significantly advanced in this area prior to the fire. The plant community covering the area analyzed in this work (71 BSG) represented an advanced, 8th stage, of succession. The study area was covered by juniper-aspen brushwood and young pine forest (Faliński 1986a, b).

The agrotechnical activities formerly performed in the research area further leveled the already flat landscape and made the depth of the humus level uniform. Surface diversification prior to the forest fire resulted from the presence of trees and juniper shrubs in particular places. Although the trees were not burnt down, it could have been predicted that after several-hours forest fire they would have been finally deleted from the patch. Hypothetically, in such a homogenous environment, secondary succession should evolve according to one spatial and chronological pattern.

\section{METHODS}

The research was carried out on a permanent research area with dimensions of $40 \times 25 \mathrm{~m}$, established (in 1992) by the Białowieża Geobotanical Station of Warsaw University (71 BSG). The area was divided into plots of $25 \mathrm{~m}^{2}$ each. The composition of species and quantity proportions of populations found in this area were studied on 5 plots (no 0 $-4)$, located in the centre and in the four corners of the research area. The phytosociological records were taken by Professor J.B. Faliński in 1993, 1995, 2000, 2002 and 2004, with the application of the decimal Londo scale for the quantitative assessment of individual species. The rates of cover from 0.1 to 0.9 in this scale correspond with plant cover from $1 \%$ to $9 \%$, and rates from 1 to 10 correspond with plant cover from $10 \%$ to $100 \%$.

\section{RESULTS}

\section{The spatial and chronological patterns of plant cover development}

After only three years from the fire in 1992 the rate of plant cover on the ground had already significantly diversified (Fig. 1). On some plots plant cover was found on the whole area of $25 \mathrm{~m}^{2}$, and on others just over a half of the plot area. In subsequent years the cover rate may increase, or at the same time a rapid decrease of cover on another plot may occur. At the end of the observation, 12 years 


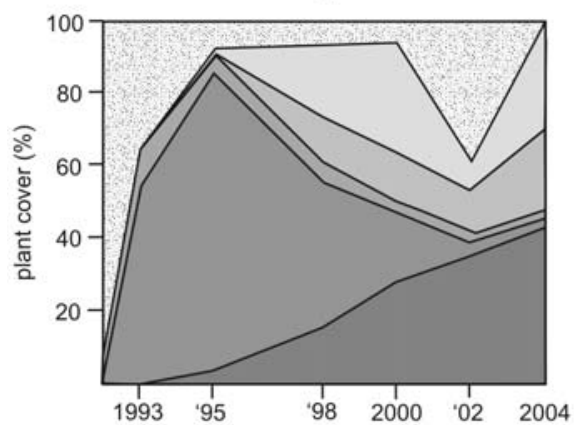

2

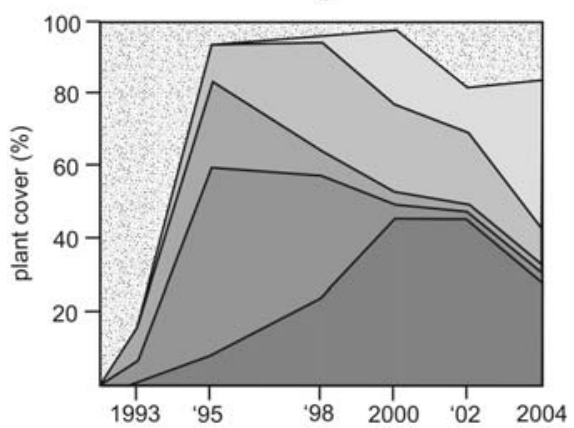

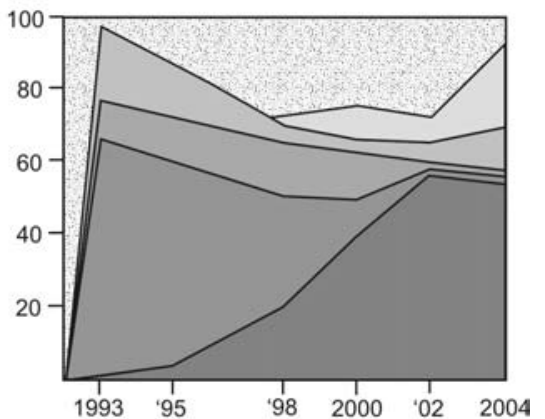

3
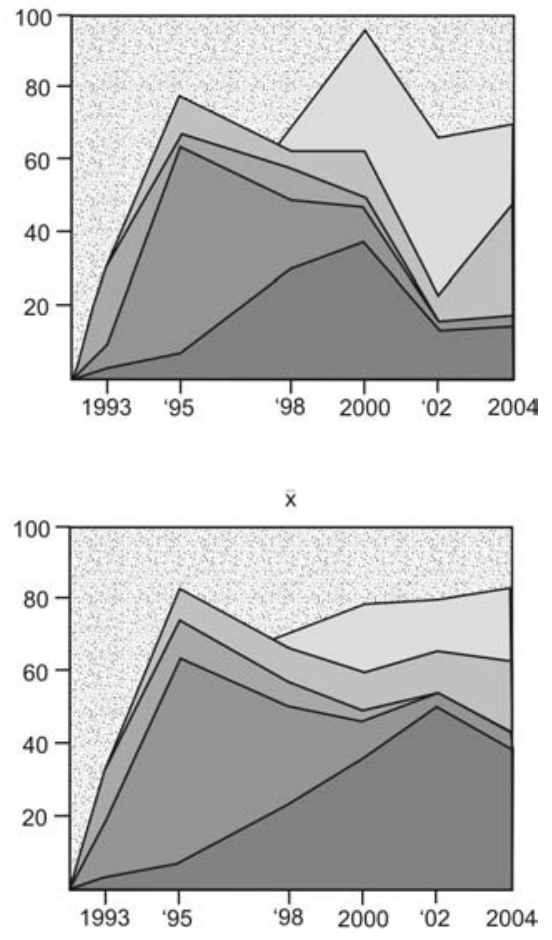

perennial grasses

bare soil

Fig. 1. Changes in the rate of cover of annuals, biennials, perennial grasses, dicotyledonous perennials, bryophytes and lichens within post-fire succession. The area of each plot is $25 \mathrm{~m}^{2}$. after the fire, the plants may entirely cover the bare land (plots 1 and 0 ), or nearly 'withdraw' from the plot and uncover the land again (plot 3).

Species with various life strategies participate in post-fire secondary succession: annuals and biennials, perennial grasses, dicotyledonous perennials, bryophytes and lichens (Table 1). Individual plots significantly differ from each other with respect to species groups proportion (Fig. 1). At the same time (1998-2000) on almost every plot different species groups dominated over the others. In the initial period (1993-1995) the plots were predominated by perennial grasses. They are the major colonists on post-fire bare ground. With respect to other species groups, they most efficiently conquer and occupy the space over the first three years. The role of perennial grasses decreases over the following years, although their species are present, but with an insignificant cover rate, until 2004 (Table 1).

There are only two grass species with different biology successful in colonization: Holcus mollis and Corynephorus canescens (Figs 2 and 3) responsible for two types of spatial patterns.
H. mollis, in the first year after the fire, already covered $40-50 \%$ of the area (plots 1 and 4 ). In the period of its domination, the co-existing species Corynephorus canescens had a low rate of cover (Fig. 2). Corynephorus canescens covered up to $20 \%$ of the area only when the number of $H$. mollis specimens decreased (after 1998). In the following years the main role was played by Calluna vulgaris. The rate of cover of heather in the last years observations increased despite presence of young specimens of aspen reaching the shrub layer (the density of Populus tremula locally reached up to $60 \%$ ). Calluna vulgaris (up to $40 \%$ cover) twelve years after the fire still is, and in all probability will be for many years, the primary structural component of the ground-layer.

In situation of Corynephorus canescens dominance (plots 0, 2 and 3) Holcus mollis is not found, or it has a very low rate of cover (Fig. 3). Although $C$. canescens, in the first year after the fire, had a significantly lower rate of cover $(<10 \%)$ than $H$. mollis, the number of $C$. canescens specimens reached its peak (40-60\% rate of cover) also after three years from the fire. $C$. canescens even colonized the plots 


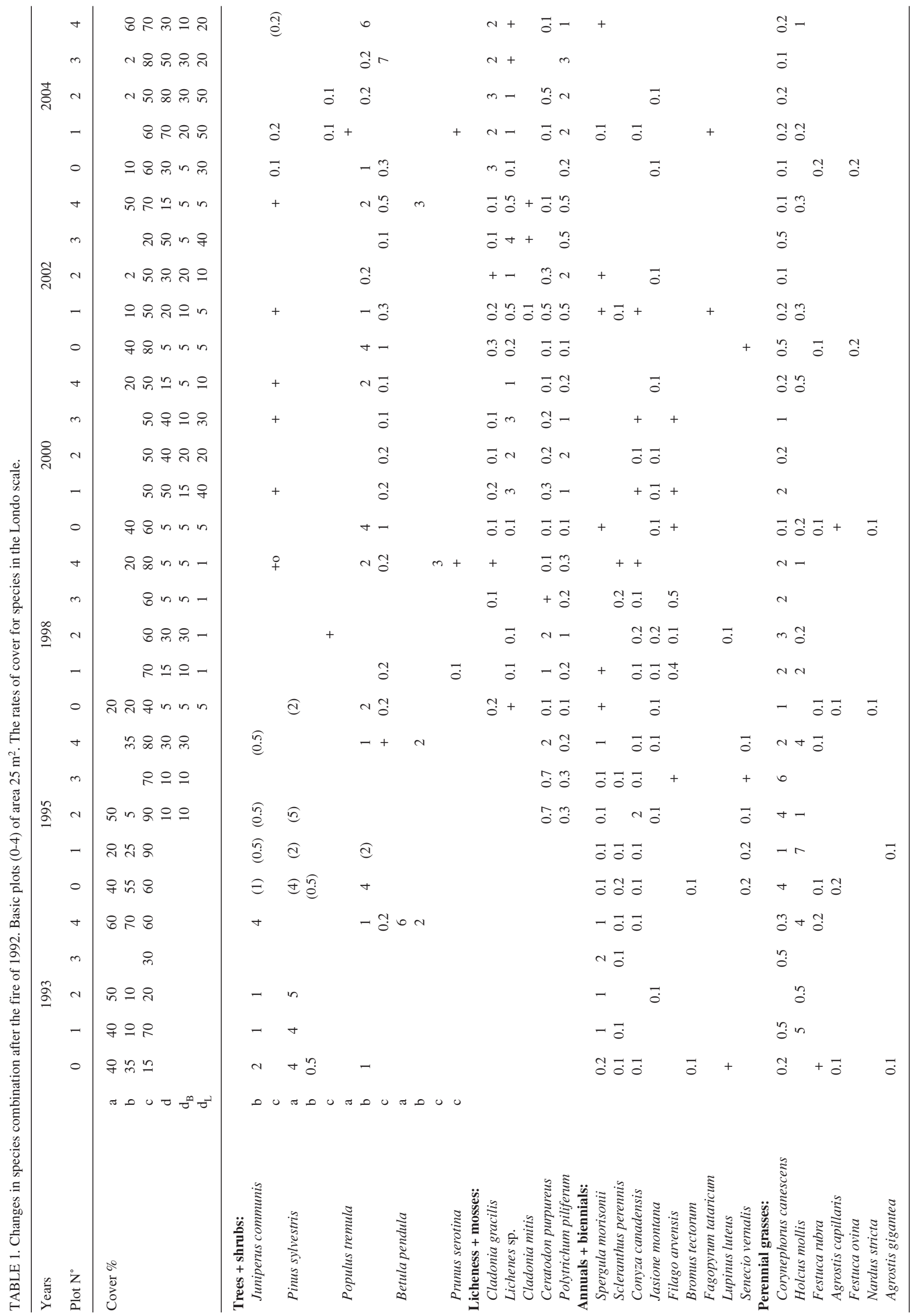




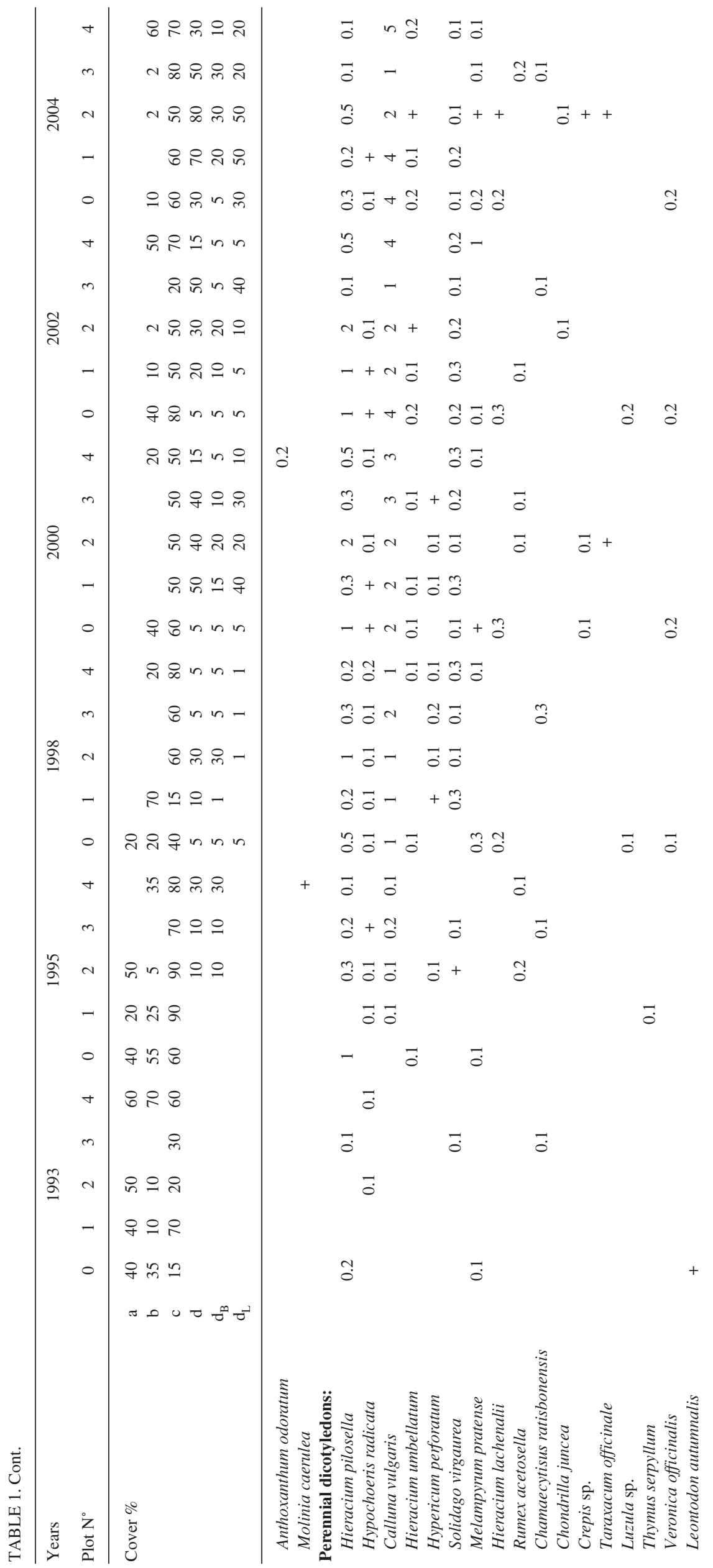

with Populus tremula brushwood. Similar to H. mollis, it 'withdraws' from the plots when Calluna vulgaris attains approximately $20 \%$ of the area. Its rate of cover after 12 years increases up to approx. $40 \%$. In this spatial pattern (in comparison to the pattern of Holcus mollis) lichens have a more significant function after the period of grasses dominance (Figs 1 and 3). Lichens and heather covered approximately $70 \%$ of the area in the last year of the research.

The chronological pattern of plant cover development is more homologous with respect to diversified spatial patterns. Firstly, grasses colonized and occupied the area on all plots within the same period (1993-1998). Secondly, the further development of plant cover (1998-2004) depended mostly on the expansion of heather clumps. When the rate of cover of Calluna vulgaris exceeded $20 \%$, the period of grass species dominance ended (Fig. 3). Thirdly, the dominance concerning the heather patch can be divided into two periods, i.e. 1998-2001 and later. In the second period from 2002, on all plots, a rapid increase in the rate of Cladonia gracilis cover $(\geq 20 \%)$ was observed.

The entering of Populus tremula on individual plots is the most chronologically differentiated. Aspen on two plots $(0,1)$ occurred in the ground-layer in 1998 , on the next two plots $(2,3)$ in 2000 , and on plot 4 - at the earliest time, already in 1993. Aspen can grow up to the shrub layer even in the first year after fire (plot 0,4$)$. Its rate of cover can gradually increase (as after 2002) up to $60 \%$ (plot 4 ), or decrease at the same time from $40 \%$ to $20 \%$. As was implied above, after the fire in 1992, Populus tremula entering the shrub layer had no influence on the creation of the chronological pattern of plant cover development.

\section{Species turnover and the model of post-fire succession}

The dominant species were determined based on the mean values of rate of cover calculated for each taxon as a mean value for five plots. Twentysix species had a mean value of cover higher than $1 \%$ (at least in one year of research). Among them the rate of cover $\geq 5 \%$ (also in at least one year) was achieved by only 10 taxa, which constituted only $25 \%$ of all species.

The maximum values of cover rate for the majority of dominants do not overlap in time (Fig. 4). The chronolo- 

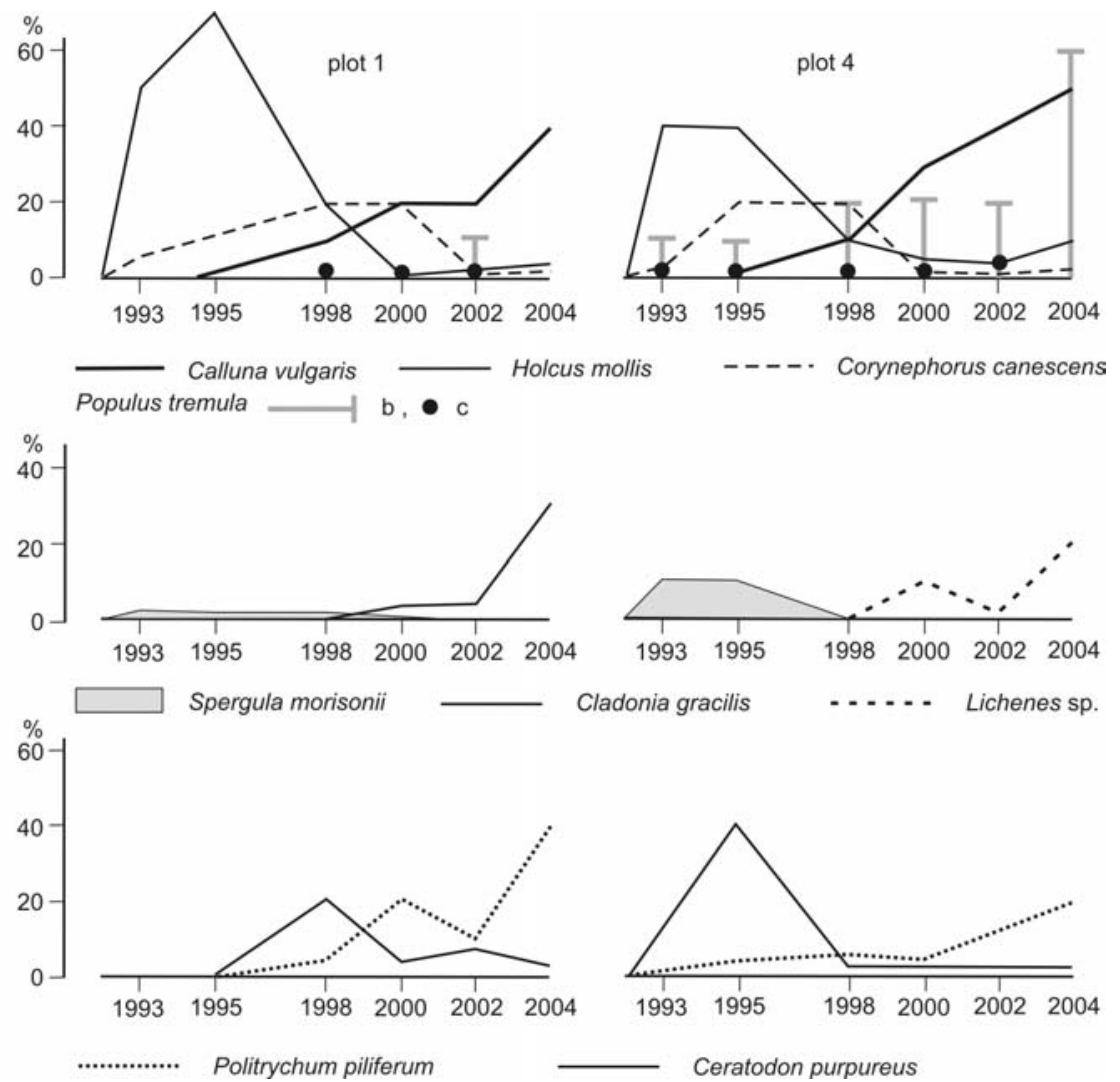

Fig. 2. The Holcus mollis pattern. The function of dominant species in post-fire succession.
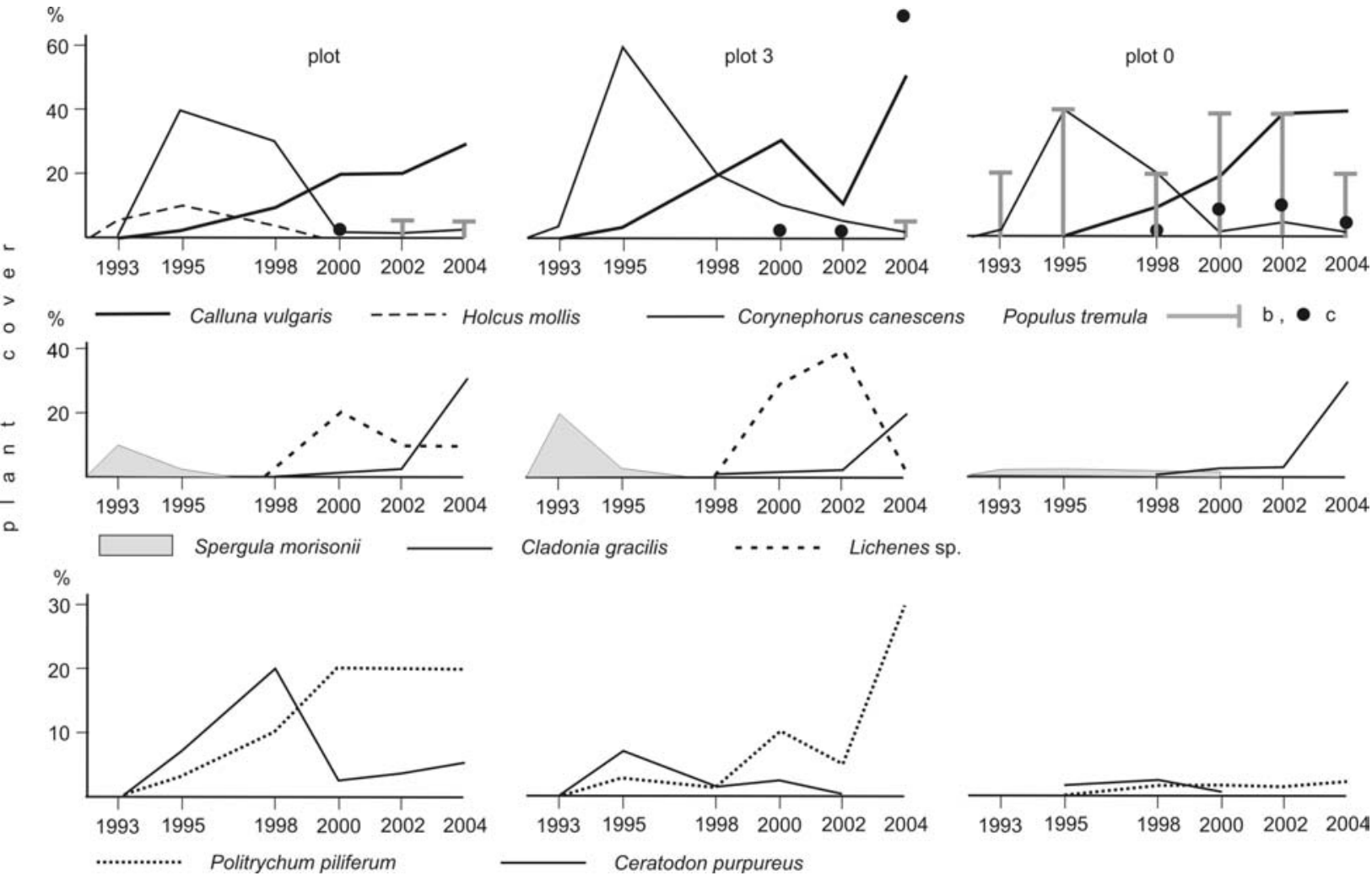

Cladonia gracilis $\quad . . . . \quad$ Lichenes sp.
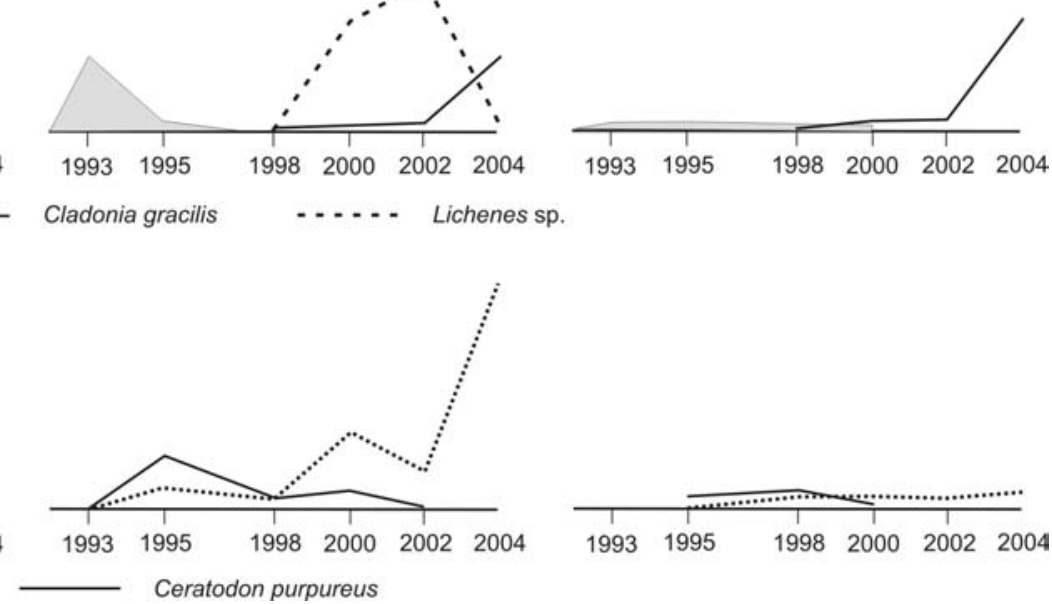

Fig. 3. The Corynephorus canescens pattern. The function of dominant species in post-fire succession.

gical overlapping of the plant cover of at least two species has been specified as a criterion for the determination of the stage of succession.

The main intersection line is determined as six years after the fire, and separates the succession process into two stages, featured by the domination of the grass species (stage 1) and heather (stage 2). Each of these stages can be divided into initial and terminal periods, in which the species with the lower rate of cover (up to $10 \%$ ) attain their maximum. 

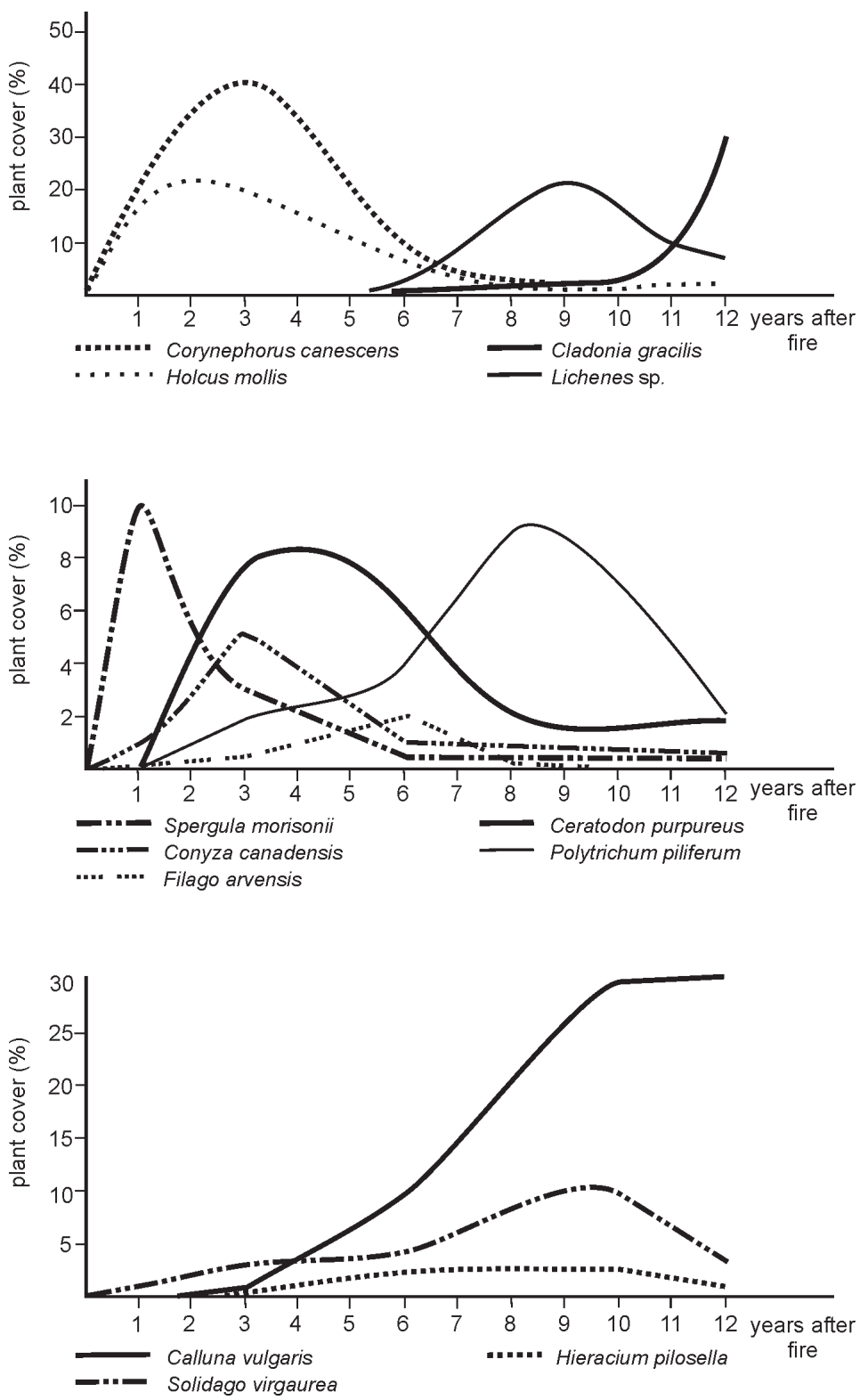

Fig. 4. Model of succession within 12 years after the fire (based on mean values of the rate of cover for selected populations).

Stage 1. A. Initial period. The first three years after the fire. It is distinguished by the highest rate of grasses cover (Corynephorus canescens - 40\%, Holcus mollis - 20\%) and the highest rate of cover of annual species (Spergula morisonii-10\%).

1.B. The terminal period of the stage. From 3rd to 6 th years after the fire. It is distinguished by a decrease in the rate of cover of dominant grass species and annual and biennial species. In this period the moss Ceratodon purpureus attains its maximal rate of cover $(8 \%)$. The share of the first species frequent for coniferous forest, i.e. Calluna vulgaris (10\%), Solidago virgaurea and Hieracium pilosel$l a$, in the cover of the ground layer increases (approx. $2 \%$ each).

Stage 2.A. Initial period. This lasts from the 6th to the 9th years after the fire. Calluna vulgaris is the dominant species. The initial period is distinguished by the mutual 'replacement' of dominant species of bryophytes. The rate of cover of Ceratodon purpureus decreases, and the rate of Polytrichum piliferum (10\%) increases. The rate of cover of lichens rapidly increases (up to 20\%).

2.B. The terminal period of the stage. It begins from 10 years after the fire. It is distinguished by an increase in the rate of cover of Cladonia gracilis. Single specimens of aspen occur in the tree layer. Populs tremula occupies 20\% of the area of shrub layer. The ground layer is predominated by Calluna vulgaris (30\%) and lichens.

\section{DISCUSSION}

Secondary succession

on abandoned fields vs secondary post-fire succession

The acreage of abandoned fields significantly increased in Europe after the Second World War in a relatively short time. After more than twenty years from the cessation of cultivation the formerly fallow lands become covered by brushwood or young forests. This process, new for the landscape and interesting for its ecological aspects, has been recorded in numerous publications. A wide range of scientific works concerning secondary succession on abandoned fields and meadows was published in the 80s and 90s (e.g. in Poland: Falińska 1989a, b; Faliński 1986a, b; Dubiel 1984; Dzwonko and Loster 1990; Michalik 1990), together with books concerning the theory (e.g. Glenn-Lewin et al. 1992 and literature cited there) and books selected objects: 
abandoned fields and meadows (Faliński 1998; Falińska 2003).

It is known that young tree stands of high density are the most susceptible to fire, including the tree stands developed as a result of secondary succession. The literature concerning post-fire succession is very abundant, but it mainly refers to the areas where fire is a constant ecological factor (e.g. Fuhlendorf and Smeins 1997a, b; Gill et al. 1981; Noble and Slatyer 1981).

It is worth emphasizing that in summer in southern Europe (Spain, France, Portugal and Italy) over 400 thousand ha of forest burns each year. 2003 and 2005 were especially tragic years with respect to this, when approx. 700 thousand hectares burnt down each year. Catastrophic fires in Poland occurred in the summer of 1992. Prevailing drought resulted in a decrease in the level of ground water, and dried litter. Additionally, the high temperature, low air humidity and strong winds enabled the fire to propagate over a large area. In total, in the year when a part of the Jelonka Reserve burnt down, fire destroyed approximately 20 thousand ha in Poland, which is a tripled mean value concerning the period 1989-1999 (Szabla and Rozwałka 1998; Hawrys et al. 1998; Błaszczak and Głuszek 1999).

Fire occurring in areas predominated by boreal forests are connected with an overdrying of the needle litter covering the floor of coniferous forests of resin-rich trees (Engelmark 1984). Fire can consume extensive areas and totally destroy the tree stand (Bradshaw 1993; De Grandpre et al. 1993; Engelmark 1993; Engelmark et al. 1993). Many scientists ascertain that in the future, also in the temperate climate zone, there will be an increasing number of fire incidents due to changes in climate conditions, an increase in the frequency and intensity of extreme events, and a widening of the differences between wet and dry seasons.

\section{Life strategies vs the chronological pattern of post-fire succession}

The fire in the Jelonka Reserve last for several hours and has been classified as a ground fire. According to the data obtained, at least a part of the pool of vegetative ramets located in the soil were not affected by the fire.

At the first stage of post-fire succession the primary function belongs to the species of perennial grasses of various strategy of growth and various biology, such as $\mathrm{Hol}$ cus mollis (guerilla strategy), creeping, rhizomatous grass and Corynephorus canescens (phalanx strategy), with tufted fibrous root system and no rhizome (Marshall 1958; Ovington and Scurfield 1956; Falińska 2003).

According to Ovington and Scurfield (1956), the horizontal length of erect Holcus mollis rhizomes on mineral soils can attain lengths of over 3 meters, which implies the potential possibility of one specimen to colonize the area. According to Harbard (1961 and quoted by Cook, 1983), a clone of Holcus mollis can have a length of $390 \mathrm{~cm}$. Clumps of Corynephorus canescens increasing its size are not able to occupy the area as fast as $H$. mollis and by vegetative reproduction. The number of Corynephorus canescens clumps can increase by over ten times within several years (e.g. from 10 to 170 clumps $/ 4 \mathrm{~m}^{2}$ within 7 years; Symonides, 1979). The high rate of cover of Holcus mollis just a year after the fire resulted from the survival of its vegetative propagules pool in the soil. The quantitative peak of Corynephorus canescens specimens was slightly delayed. Some ra- mets in large clumps survived the fire. They fructified a year after the fire and provided generative offspring which resulted in the increase of the area occupied by this species.

In the case of annual plant species co-existing with the grass species in the initial period of post-fire succession, it is difficult to ascertain whether their diaspores survived the fire in the soil seed bank, or have an egzogenic origin. However, it is known that both Spergula morisonii and Conyza canadensis produce a high quantity of diaspores $(C$. canadensis up to approx. 75,000 per specimen, S. morisonii up to approx. 650 per specimen; Symonides 1988). Thus, their transfer by means of wind from the surrounding postfire area is of high probability.

Despite different biology, these four species have the same pattern of population dynamics. They are distinguished by the rapid increase in number of specimens at the stage of colonization of the post-fire area, and the same rapid decrease in number (without a stage of relative quantitative balance). Falińska (1997) asserts that the rapid decrease in the number of specimens can be specific for the populations of perennial species which colonize free space. The author also states that the "stage of population regression, until the population declines in a particular area, is typical of pioneering species and the components of communities of the initial succession stage", which finds confirmation in the studied case.

The dormant root buds of Populus tremula also survived the fire. This explains the presence of aspen brushwood in some places already in the first year after the fire. The vegetative propagation of this species is significantly stimulated both by forest felling and fire. According to Tkačenko (1952) the roots (and also the root offshoots) extend to a distance of over $20 \mathrm{~m}$ from the trunk. The presence of aspen in the ground-layer and shrub-layer does not influence the chronological differentiation of the initial stage. However, it may result in decreasing the duration of the preforest stage. The mechanisms of the direct influence of aspen on the co-existing plant species have been poorly researched. It is assumed that some importance can be ascribed to mycorrhiza (Obmiński 1973). The research on fungal flora in the Jelonka post-fire area shows a rapid increase in the number of mycorrhizal species from genera Leecium, Amantia, Paxillus and Carinarius within the first three years after the fire (Kałucka and Sumorok 1996). Unfortunately, the plant species, associated with these fungi, whose roots propagate underground in the third year after the fire, were not specified.

However, it is known that species from the Ericacae family are symbiotic with mycorrhizal fungi. Perhaps the intensive increase in the rate of cover of Calluna vulgaris, delayed until 6 years after the fire, was determined by the recovery of the mycorrhizal fungi destroyed by the fire. Clumps of heather expanded gradually from the above ground shoots that survived the fire. The occupation of almost a half of the area by the over ground shoots of heather 12 years from the fire totally changed the interactions between the species above and under the ground. In practice, the same species participate in the process of secondary succession in the Jelonka Reserve, both on fallow land after years and on postfire areas. In the second case the process evolves significantly faster. The survival of some buds of the species with vegetative propagation considerably increases the speed of the process evolving towards forest community creation. 
The model of stages in secondary succession on fallow land $v s$ the model of post-fire secondary succession

Usher (1992) presented a statistical model of succession in which periods of relative discontinuity could be defined despite continuous quantitative changes over time. In this model the population dynamics of 30 statistical populations resulted from theoretically assumed values of mortality and reproduction rates. The stages of succession were defined based on species dominance and distinctive species combinations.

The model of post-fire succession obtained in this research by the author is very similar to Usher's theoretical model. The sequence of succession stages is a consequence of the dynamics of individual populations. The presented succession model (Fig. 4) does not reflect factual events which occurred in a specific space and real time. However, the presented spatial patterns of plant cover development in a defined place (plot) are real. In the succession model the values of the rate of cover for individual species, their chronological sequence and the year of maximum quantity are statistical factors. These factors are based on mean values calculated from empirically obtained results. As a consequence, such determined stages of succession are abstractive types. The method of their determination is the same as used by Usher (1992), and only the parameters of population dynamics were obtained empirically.

Faliński (1986a, b) defined three stages of succession by the simultaneous comparison of the combination of species in the research areas established on fallow land abandoned in different periods.

Faliński (1998) defined the succession process as the sequence of identifiable communities: from Teesdaleo-Arnoseridetum to Peucedano-Pinetum. The author is close to the classic succession theory by Clements $(1928,1936)$. The succession process evolves typically from grassland, through brushwood community to spontaneous forest, and these separate stages are defined by the author as "initial stage, optimal stage, terminal stage" (Faliński 1998).

The present author has an approach which is different from the above-mentioned, both with respect to the adopted theory and the applied research method. The succession process is comprehended as the result of population dynamics, in which the main function is fulfilled by the populations able to successfully colonize and occupy the conquered space. Different spatial and chronological patterns concerning the initial stage of post-fire succession provided in this research work imply the significance of random events (e.g. the survival of vegetative propagules in a particular area). The patterns seem to be more uniform over time. The 'space occupation' (Begon and Mortimer 1981) of Calluna vulgaris will probably determine the resources of free space being subject to the competition of subsequently occurring pine forest species for decades.

\section{ACKNOWLEDGMENTS}

Heartfelt thanks to Ms Halina Kościelecka and Ms Alicja Wiktoruk of the Białowieża Geobotanical Station of Warsaw University, for the preparation of drawings and the typescript for publishing.

This study is supported by project KBN 3 P04F 04624.

\section{LITERATURE CITED}

BEGON M., MORTIMER M. 1981. Population ecology. A unified study of animals and plants. Blackwell Scientific Publications.

BŁASZCZAK E., GŁUSZEK A. 1999. Nadleśnictwo Myszyniec. Monografia Śląska Agencja Reklamy i Marketingu, Chorzów. (in Polish)

BRADSHAW R. 1993. Tree species dynamics and disturbance in three Swedish boreal forest stands during the last two thousand years. J. Veget. Scien. 4.

CIEŚLIŃSKI S. 1993. Atlas: Lichenes. Phytocoenosis (N.S.) 5 Suppl. Cartogr. Geobot. 3: 105-130.

CLEMENTS F.E. 1928. Plant succession and Indicators. H.W. Wilson, New York.

CLEMENTS F.E. 1936. Nature and structure of the climax. J. Ecol. 24: 252-284.

COOK R.F. 1983. Clonal Plant Populations. Amer. Scien. 71: 244-253

CZYŻEWSKA K. 1993. Atlas: Bryophyta. Phytocoenosis (N.S.) 5 Suppl. Cartogr. Geobot. 3: 81-104.

DE GRANDPRE L., GAGNON D., BERGERON Y. 1993. Changes in the understory of Canadian southern boreal forest after fire. J. Veget. Scien., 4.

DUBIEL E. 1984. Dolina Wierzbanówki: 5. Rozwój roslinności na odłogach. Zesz. Nauk. Uniw. Jagiell., Prace Bot. 12: 97112. (in Polish with English summary)

DZWONKO Z., LOSTER S. 1990. Vegetation differentiation and secondary succession on a limestone hill in southern Poland. J. Veget. Sci. 1: 615-622.

ENGELMARK O. 1984. Forest fires in the Muddus national park (northern Sweden) during the past 600 years. Can. J. Bot. 62 .

ENGELMARK O. 1993. Early post-fire tree regeneration in a Picea-Vaccinium forest in northern Sweden. J. Veget. Scien. 4.

ENGELMARK O., BRADSHAW R., BERGERON Y. 1993. Disturbances dynamics in boreal forest. J. Veget. Sci. 4.

FALIŃSKA K. 1989a. Plant population processes in the course of forest succession in abandoned meadows. I. Variability and diversity of floristic compositions, and biological mechanisms of species turnover. Acta Soc. Bot. Pol. 58: 439-465.

FALIŃSKA K. 1989b. Plant population processes in the course of forest succession in abandoned meadows. I. Demography of succession promoters. Acta Soc. Bot. Pol. 58: 467-491.

FALIŃSKA K. 1997. Ekologia roślin. Podstawy teoretyczne, populacja, zbiorowisko, procesy. Wydawnictwo Naukowe PWN, Warszawa. (in Polish)

FALIŃSKA K. 2003. Alternative pathways of succession: species turnover patterns in meadows abandoned for 30 years. Phytocoenosis (N.S.) 15 Arch. Geobot. 9: 1-104.

FALIŃSKI J.B. 1986a. Sukcesja roślinności na nieużytkach porolnych jako przejaw dynamiki ekosystemu wyzwolonego spod długotrwałej presji antropogenicznej. Część 1. Vegetation succession of abandoned farmland as a dynamics manifestation of ecosystem liberal, of long continuance anthropopression. Part 1. Wiad. Bot. 30.1: 21-50. (in Polish)

FALIŃSKI J.B. 1986b. Sukcesja roślinności na nieużytkach porolnych jako przejaw dynamiki ekosystemu wyzwolonego spod długotrwałej presji antropogenicznej. Część 2. Vegetation succession of abandoned farmland as a dynamics manifestation of ecosystem liberal, of long continuance anthropopression. Part 2. Wiad. Bot. 30.2: 115-126. (in Polish)

FALIŃSKI J.B. 1993. Atlas: Plantae vasculariar. Phytocoenosis (N.S.) 5 Suppl. Cartogr. Geobot. 3: 51-80.

FALIŃSKI J.B. 1998. Dioecious woody pioneer species (Juniperus communis, Populus tremula, Salix sp. div.) in the secondary succession and regeneration. Phytocoenosis N.S. 10 Suppl. Cartogr. Geobot. 8: 1-156.

FALIŃSKI J.B., HOLEKSA J. 1993. Atlas: Plantae vasculariar. Phytocoenosis (N.S.) 5 Suppl. Cartogr. Geobot. 3: 51-80. 
FUHLENDORF S.D., SMEINS F.E. 1997a. Long-term vegetation dynamics mediated by herbivores, weather and fire in a Juniperus-Quercus savanna. J. Veget. Scen. 8: 19-28.

FUHLENDORF S.D., SMEINS F.E 1997b. Long-term importance of grazing, fire and weather patterns on Edwards Plateau vegetation change. In: C.A. Taylor (ed.) Proceedings of Juniper Symposium, 7.19-7.20. Texas, Agricultural Experiment Station. Technical Report 97-1. College Station, TX.

GILL A.M., GRAVES R.H., NOBLE I.R. (eds). 1981. Fire and the Australian Biota. Australian Academy of Science, Canberra.

GLENN-LEWIN D.C., PEET R.K., VEBLEN T.T. (eds). 1992. Plant succession. Theory and prediction. Chapman \& Hall, London.

HAWRYŚ Z., ZWOLIŃSKI J., MATUSZCZYK I., OLSZEWSKA G., ZWOLIŃSKA B., BATKO B., 1998. Zmiany i odbudowa ekosystemów leśnych zniszczonych przez pożar na przykładzie wielkoobszarowego pożarzyska w lasach Rudzko-Rudziniecko-Kętrzyńskich. Postępy Techniki w Leśnictwie 67. (in Polish)

KAŁUCKA I., SUMOROK B. 1996. Makromycetes w zbiorowiskach roślinnych podlegających sukcesji wtórnej nie zaburzonej i zaburzonej pożarem na gruntach porolnych w Rezerwacie Jelonka (Polska NE). Macromycetes in the plant communities under the non-disturbed and fire-disturbed secondary succession on the abandoned farmlands in the Jelonka Reserve (N.E. Poland). Phytocoenosis (N.S.) 8 Sem. Geobot. 4: 123-136. (in Polish with English summary)

KORNAŚ J. 1958, Succession régressive de la végétation de garrigue sur calcaires compacts dans la Montagne de la Gardiole près de Montpellier. Acta Soc. Bot. Pol. 27.4: 563-596.
MARSHALL J.K. 1958. Corynephorus canescens (L.) Beauv. J. Ecol. 55: 207-220.

MICHALIK S. 1990, Przemiany roślinności kserotermicznej w czasie 20-letniej sukcesji wtórnej na powierzchni badawczej "Grodzisko" w Ojcowskim parku Narodowym. Prądnik. Prace Muz. Szafera 2: 43-52. (in Polish)

NOBLE I.R., SLATYER R.O. 1981. Concepts and models of succession in vascular plant communities subject to recurrent fire. In: A.M. Gill, R.H. Graves, I.R. Noble (eds), Fire and the Australian Biota. Australian Academy of Science, Canberra.

OBMIŃSKI Z. 1973. Ekologia osiki. In: S. Białobok (ed.). Topole Populus L. PWN, Warszawa-Poznań. (in Polish)

OVINGTON J.D., SCURFIELD G. 1956. Holcus mollis L. J. Ecol. 44.1: 272-280.

SYMONIDES E. 1979. The structure and population dynamics and psammophytes on inland. I. Populations of initial stages. Ekol. Pol. 27.2: 191-234

SYMONIDES E. 1988. Population dynamics of annual plants. In: A.J. Davy, M.J. Hutchings, A.R. Watkinson (eds), Plant population ecology, pp. 221-248. Blackwell Scientific Publications.

SZABLA K., ROZWAŁKA Z. 1998. Odnowienie lasu i ochrona upraw powstałych na wielkim pożarzysku w Nadleśnictwie Rudy Raciborskie. Postępy Techniki w Leśnictwie.

TKAČENKO M.E. 1952. Obščeje Lesovodstvo. Moskwa-Leningrad.

USHER M.B. 1992. Statical models of succession. In: D.C. Glenn-Lewin, R.K. Peet R.K., T.T. Veblen (eds). Plant succession. Theory and prediction. Chapman \& Hall, London.

WILER K. 1996. Instrukcja ochrony przeciwopożarowej obszarów leśnych. MOŚZNiL, Warszawa. (in Polish) 